\title{
Correlation and Path Coefficient Analysis of Kopyor Dwarf Coconut (Cocos nucifera L.)
}

\author{
Miftahorrachman ${ }^{1}$, Sukmawati Mawardi ${ }^{2}$ and Hengky Novarianto ${ }^{3}$
}

\begin{abstract}
Breeding programs of kopyor dwarf coconut require a population base with high genetic diversity especially for characters that relate to fruit production. The study aims to determine the appearance of three kopyor dwarf coconuts from Pati District and correlations among 13 characters of Kopyor Green Dwarf, Kopyor brown dwarf, and Kopyor Yellow Dwarf and to study twelve vegetative and generative characters which directly and indirectly affect the number of fruits. The study was conducted at The Paniki Experimental Garden, North Sulawesi, Indonesia from August 2015 to February 2016. The design used was randomized block design with three treatments and three replications. Observed thirteen characters including number of bunches (NB), number of fruit (NF), number of leaves (NL), number of leaflets (NLL), width of leaflets (WLL), length of the leafleats (LLL), length of petiole (LP), width of petiole (WP), thick of petiole (TP), length of rachis (LR), length of leaf (LL), height of stem (HS), and girth of stem (GS). Path analysis among morphological characters to number of fruits was worked out using the formula of Singh and Chaudary. Results of variance analysis showed Kopyor Green Dwarf and Kopyor Brown Dwarf significantly differed from Kopyor Yellow Dwarf. Results of simple correlation analysis found no correlation among twelve characters with number of fruits for the three kopyor dwarf coconut, but the results of the path analysis of characters NL $(\mathrm{r}=0.5627)$, NLL $(\mathrm{r}=0.5920)$, HS $(\mathrm{r}=0.4861)$, and GS $(\mathrm{r}=0.6123)$ for the Kopyor Green Dwarf; NB ( $\mathrm{r}=0.4241)$, LP $(\mathrm{r}=0.6390)$, WP $(\mathrm{r}=0.8705)$, LR $(\mathrm{r}=0.5235)$, and LL $(\mathrm{r}=0.6257)$ for the Kopyor Brown Dwarf; and WLL $(r=0.8413)$, LLL $(r=0.5617)$, TP $(r=0.5864)$, LR $(r$ $=1.5795)$, and LL $(r=1.0228)$ for the Kopyor Yellow Dwarf directly affect the number of fruits. These characters can be used for basic selection in breeding of kopyor coconut.
\end{abstract}

Key words: Kopyor, correlation, direct and indirect effects, yield

\footnotetext{
${ }^{1}$ Senior Researcher, Indonesian Palmae Research Institute (IPRI), Jl. Raya Mapanget, P.O. Box 1004, North Sulawesi, Indonesia. Email: miftahorrachman@gmail.com

${ }^{2}$ Young Researcher, Indonesian Palmae Research Institute (IPRI), J1. Raya Mapanget, P.O. Box 1004, North Sulawesi, Indonesia. Email: umma.mawardi@gmail.com

${ }^{3}$ Senior Researcher, Indonesian Palmae Research Institute (IPRI), J1. Raya Mapanget, P.O. Box 1004, North Sulawesi, Indonesia. Email: hengkynovarianto@yahoo.com
} 


\section{Introduction}

Kopyor (Makapuno in Philippines) is one of the exotic coconut in Indonesia that has a high economic value due to the characteristics of loose endosperm, savory crumbs, and regardless of the shell. The unique flavor and distinctive texture of kopyor coconut makes it highly favorite of consumers but the abnormality in the endosperm results in the embryo being unable to germinate naturally. So, the development of kopyor coconut populations has been very limited. Kopyor coconut seedlings can be obtained from zygotic embryos through embryo culture techniques (Maskromo et al, 2015). However, the development of an embryo culture technique is still encountering many obstacles and the number of seedlings produced are still very limited. Besides, time and cost required are also high and so the price of kopyor seedlings becomes unaffordable to the farmers.

Kopyor dwarf coconut from Pati District, Central Java has some advantages in terms of the percentage of kopyor fruits per bunch as compared to the tall kopyor types. The nature of self-pollination in dwarf coconut types makes the percentage of kopyor fruits per bunch higher $(15-20)$ than that in the cross-pollinated tall kopyor coconut (5-10). Segregation of Kopyor dwarf coconut is lower than that kopyor tall coconut, so it is very easy to be developed by farmers. However, in order to successfully develop kopyor dwarf coconut, further study on morphological characters and relationship with yield are needed, so that selection is more robust.

An understanding of the relationship between the characters will help in deciding which characters can be used in the selection for the improvement of crop yield. The correlation coefficient is used to measure the relationship between characters of diverse plants and to determine which characters can be used as selection criteria in crop improvement. In sagu baruk (Arenga macrocarpa), Tenda and Miftahorrachman (2014) found that height characters of stem, length of rachis, length of petiole, number of leaflets, weight of stem, and weight of pith can be used in selection criteria for crop improvement.
Analysis of the correlation between the yield and the yield components are very important in determining the selection criteria. Therefore path analysis can help determine the effects of direct and indirect components on yields (Yucel et al., 2006; Rohaeni and Permadi, 2012). Understanding of the interrelationship between characters in the plant is very helpful in determining which character should be used as selection criteria in crop improvement program. The correlation coefficient measures the mutual relationship between the characters of plants and aids to determine which characters can be used for improvement in associated complex characters such as yield (Gelalcha and Hanchinal, 2013; Wright, 1921 in Ali et al., 2013).

Yield is a complex character and selection for yield and yield components should receive the most attention (Reddy et al, 2013). According to Ejaz-ul - Hasan et al. (2014), yield is a complex character which depends on other morphological characters that are mostly inherited quantitatively. It is therefore important to study the contribution of each character especially the impact on the yield. Iqbal et al., (2013) stated that yield is a complex character and is a function of several components of the character and the interaction of these characters with the environment. Ahamed et al., (2015) stated that the success of the breeding program through program selection can only be achieved by utilizing valid information about correlation and genetic diversity of the characters to improve the plant and depends on the amount of diversity in the population.

The correlation coefficient is a parameter used to evaluate the relationship between the characters. The positive correlation between characters indicates that if one character increases, other characters will also increase. In contrast, negative correlation indicates that if a character increases other characters will decrease (Krualee et al., 2013).

Selection is based primarily on phenotypic characters as the main technique used in breeding programs. Selection response depends on many factors such as the relationship 
between the characters. By knowing the relationship between the characters, the interpretation of previous results will become easier (Huang et al., 2013).

When initiating a breeding program with plants which have genetic variation, it is important to gather information on the traits of agronomic characters for selection and production of better varieties. The relationship of different traits with yield, their direct and indirect effects on one another provides basis for a successful breeding programme (Assahun et al., 2013).

This study aims to determine the appearance of three varieties dwarf coconut derivative F1 from Pati District and correlations among 13 characters of Kopyor Green Dwarf, Kopyor Brown Dwarf, and Kopyor Yellow Dwarf and the effect of twelve vegetative and reproductive characters, which directly and indirectly affect the yield of the three kopyor dwarf coconut.

\section{Materials and Methods}

The experiment was conducted during August 2015 to February 2016 at The Paniki Experimental Garden, Manado, North Sulawesi. The research location is situated at an altitude of approximately 80 meters above sea level, with rainfall ranging between 2500-3000 mm/year, climate type A according to Schmidt and Ferguson, as well as a kind of alluvial soil. Experiments using a randomized block design with three treatments and three replications. The treatments consisted of 4-year-old plants of Kopyor Green Dwarf coconut (KGD), Kopyor Brown Dwarf (KBD), and Kopyor Yellow Dwarf (KYD). These population is the first derivative (F1) of the population of Kopyor Dwarf coconut from Pati District, Central Java. Each experimental unit consisted of 20 plants.

Observation of number of bunches (NB: number/plant), number of fruit (NB: number/bunch), number of leaves (NL: number/plant), number of leaflets (NLL: number/lamina), width of leaflets (WLL: $\mathrm{cm}$ ), length of the leaflet (LLL: cm), length of petioles (LP: $\mathrm{cm})$, width of petiole (WP: $\mathrm{cm}$ ), thick of petiole (TP: cm), length of rachis (LR: $\mathrm{cm}$ ), length of leaf (LL: cm), height of stem(HS: $\mathrm{cm})$, girth of stem (GS: $\mathrm{cm}$ ) were recorded. In addition to morphological characters, the chlorophyll content in the three kopyor dwarf coconuts were also analyzed in laboratory. The data of morphological characters collected were analyzed using analysis of variance (ANOVA), and when appropriate, means were separated using honestly significant difference (HSD) test.

Coefficient of variance is calculated based on the formula of Singh and Chaudary (1977) :

$$
\text { C. } V=\frac{S D}{X} X 100
$$

The correlation coefficient between the characters is calculated with reference to the matrix method as proposed by Singh and Chaudary (1977) as follows

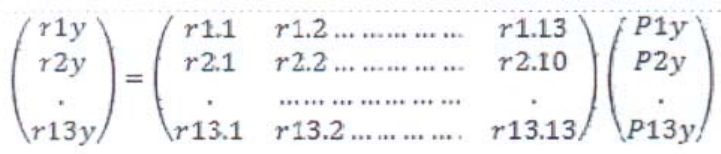

B

Vector $A$ is a correlation between character (Xi) and yield (Y)(Riy). The components of the matrix $B$ consists of parameter correlation of $\mathrm{Xi}(\mathrm{rij})$, while the vector $\mathrm{C}$ are components that directly influence variables $\mathrm{Xi}$ to $\mathrm{Y}$ (Pij). Estimate the vector $\mathrm{C}$ using formula :

$$
\mathrm{C}=\frac{1}{\mathrm{~B}} \mathrm{XA}
$$

Each calculation of the above formula can be explained as follows:

B, was calculated using a software program Minitab release 16

$\frac{1}{B}$ inverse matrix by using a software program Lotus 123 Release 5

C, calculated using Lotus 123 Program Release 5

The effect of indirect Xi measured by Cjrij 
Partial correlation coefficients were tested using the formula :

$t=r \sqrt{\frac{\mathrm{n}-2}{1-r^{2}}}$

$\mathrm{t}$ value compared with $\mathrm{t}(0: 05,58)$

\section{Result and Discussion}

Appearance of Vegetative and Reproductive Characters of Three Kopyor Dwarf Coconut.

Performance of thirteenth vegetative and reproductive characters of the Kopyor Green Dwarf, Kopyor Brown Dwarf, and Kopyor Yellow Dwarf showed differences growth which varied with the diversity coefficient above 20 percent (Table 1). Kopyor Yellow Dwarf is the most diverse in growth characters. From the observed 13 characters, 10 character had higher coefficient of variation, ranging between 21.61 percent and 40.44 percent, while the rest characters are relatively uniform. These character are namely, number of leaflets, widht of leaflets, and girth of stem.

Eight characters of Kopyor Green Dwarf coefficient variance values ranged between 20.96 percent to 36.20 percent while number of leaflets, length of leaflets, lenght of petiole, thick of petiole, and girth of stem had more uniformity. According to Hartati et al. (2012), character with high genetic diversity has potential to use in crops improvement because it has a chance of selection greater than character with a narrow diversity.

Kopyor Brown Dwarf showed the most uniform growth. From the 13 characters observed, only six characters varied with coefficient variance values ranging from 20.00 percent to 36.34 percent. The number of characters with diverse growth provides an opportunity to be selected in order to improve the plant. But the correlation between characters that vary with production needs to be tested further, especially its correlation with yield or fruit production.
Results of HSD test of thirteen characters (Table 2) from the three kopyor dwarf coconut from Pati show six characters between Kopyor Green Dwarf and Kopyor Brown Dwarf not significantly different, but both of them were significantly different with Kopyor Yellow Dwarf. Distingushing characters are number of bunches, lenght of leaflets, lenght of petiole, thick of petiole, lenght of rachis, and lenght of leaf, while, there is no differences between Kopyor Green Dwarf and Kopyor Brown Dwarf. In general, appearance of Kopyor Brown Dwarf is more vigorous than that Kopyor Green Dwarf and Kopyor Yellow Dwarf and the weakest in vigour was Kopyor Yellow Dwarf. The data in Table 2 indicate that leaf characters of Kopyor Brown Dwarf as a photosynthesis media is better than leaf character of Kopyor Green Dwarf and Kopyor Yellow Dwarf. The average number of leaf, number of leaflets, width leaflets, and length of leaflets of Kopyor Brown Dwarf was higher than Kopyor Green Dwarf and Kopyor Yellow Dwarf.

Based on the analysis of chlorophyll content of the three kopyor dwarf coconuts (Table 3), Kopyor Brown Dwarf had the highest content of both chlorophyll a and chlorophyll b, while Kopyor Yellow Dwarf had the lowest chlorophyll content. It is suspected that vigour of Kopyor Yellow Dwarf is the weakest. Xanthophyll is the pigment in algae causing algae into a brown color, so that the alleged Kopyor Brown Dwarf also contains pigment xanthophylls (blog.ub.ac.id). Xanthophyll as pigments of co-sensitization has a role to absorb light for photosynthesis and reduce excess light energy to avoid damage to the photosynthetic system (Dwitasari, 2014). This may cause Kopyor Brown Dwarf as the most vigorous coconut palm than the two other kopyor dwarf coconut even when encountering dry season for a long period.

Sirait (2008) mentioned that there are two kinds of chlorophyll, chlorophyll a $\left(\mathrm{C}_{55} \mathrm{H}_{72} \mathrm{O}_{5} \mathrm{~N}_{4} \mathrm{Mg}\right)$ and chlorophyll b $\left(\mathrm{C}_{55} \mathrm{H}_{70} \mathrm{O}_{6} \mathrm{~N}_{4} \mathrm{Mg}\right)$. According to Nio Ai Song and Banyo (2011), three main function of chlorophyll in photosynthesis is the process of utilizing solar energy, triggering the fixation of 
Table 1. Mean value of thirteen growth characters from three kopyor dwarf coconut

\begin{tabular}{|c|c|c|c|c|c|}
\hline No. & \multicolumn{2}{|l|}{ Character } & $\begin{array}{c}\text { Kopyor Green Dwarf } \\
9.91\end{array}$ & $\begin{array}{c}\text { Accessions } \\
\text { Kopyor Brown } \\
\text { Dwarf }\end{array}$ & $\begin{array}{c}\begin{array}{c}\text { Kopyor Yellow } \\
\text { Dwarf }\end{array} \\
7.22\end{array}$ \\
\hline 1. & Number of bunches (NB) & $\begin{array}{l}\mathrm{X} \\
\mathrm{Sd} \\
\mathrm{CV}(\%)\end{array}$ & $\begin{array}{c}9.91 \\
2.61 \\
\mathbf{2 6 . 3 3}\end{array}$ & $\begin{array}{c}10.17 \\
2.57 \\
\mathbf{2 5 . 2 7}\end{array}$ & $\begin{array}{l}7.22 \\
2.92 \\
\mathbf{4 0 . 4 4}\end{array}$ \\
\hline 2. & Number Of Fruits (NF) & $\begin{array}{l}\mathrm{X} \\
\mathrm{Sd} \\
\mathrm{CV}(\%)\end{array}$ & $\begin{array}{c}7.68 \\
1.99 \\
\mathbf{2 5 . 9 6}\end{array}$ & $\begin{array}{c}7.24 \\
2.63 \\
\mathbf{3 6 . 3 4}\end{array}$ & $\begin{array}{l}7.04 \\
1.96 \\
\mathbf{2 7 . 9 2}\end{array}$ \\
\hline 3. & Number of leaves (NL) & $\begin{array}{l}\mathrm{X} \\
\mathrm{Sd} \\
\mathrm{CV}(\%)\end{array}$ & $\begin{array}{c}13.17 \\
2.80 \\
\mathbf{2 1 . 3 0}\end{array}$ & $\begin{array}{c}14.97 \\
2.63 \\
17.58\end{array}$ & $\begin{array}{l}11.55 \\
2.91 \\
\mathbf{2 5 . 2 3}\end{array}$ \\
\hline 4. & Number of leaflets (NLL) & $\begin{array}{l}\mathrm{X} \\
\mathrm{Sd} \\
\mathrm{CV}(\%)\end{array}$ & $\begin{array}{c}87.00 \\
6.05 \\
6.96\end{array}$ & $\begin{array}{c}85.09 \\
7.77 \\
9.14\end{array}$ & $\begin{array}{l}78.07 \\
14.98 \\
19.19\end{array}$ \\
\hline 5. & Width of Leaflets (WLL) $(\mathrm{cm})$ & $\begin{array}{l}\mathrm{X} \\
\mathrm{Sd} \\
\mathrm{CV}(\%)\end{array}$ & $\begin{array}{c}3.99 \\
0.93 \\
\mathbf{2 3 . 2 9}\end{array}$ & $\begin{array}{c}4.09 \\
0.82 \\
\mathbf{2 0 . 0 0}\end{array}$ & $\begin{array}{l}3.84 \\
0.74 \\
19.17\end{array}$ \\
\hline 6. & Length of leaflets (LLL) $(\mathrm{cm})$ & $\begin{array}{l}\mathrm{X} \\
\mathrm{Sd} \\
\mathrm{CV}(\%)\end{array}$ & $\begin{array}{c}101.30 \\
15.39 \\
15.19\end{array}$ & $\begin{array}{c}105.51 \\
14.71 \\
13.94\end{array}$ & $\begin{array}{l}87.42 \\
18.89 \\
\mathbf{2 1 . 6 1}\end{array}$ \\
\hline 7. & Length of Petiole (LP) (cm) & $\begin{array}{l}\mathrm{X} \\
\mathrm{Sd} \\
\mathrm{CV}(\%)\end{array}$ & $\begin{array}{l}143.24 \\
26.85 \\
18.75\end{array}$ & $\begin{array}{l}146.03 \\
22.04 \\
15.09\end{array}$ & $\begin{array}{l}120.11 \\
30.10 \\
\mathbf{2 5 . 0 6}\end{array}$ \\
\hline 8. & Width of Petiole (WP) (cm) & $\begin{array}{l}\mathrm{X} \\
\mathrm{Sd} \\
\mathrm{CV}(\%)\end{array}$ & $\begin{array}{c}5.04 \\
1.82 \\
\mathbf{3 6 . 2 0}\end{array}$ & $\begin{array}{c}6.33 \\
0.77 \\
12.16\end{array}$ & $\begin{array}{c}5.01 \\
1.90 \\
\mathbf{3 7 . 9 2}\end{array}$ \\
\hline 9. & Thick of Petiole (TP) $(\mathrm{cm})$ & $\begin{array}{l}\mathrm{X} \\
\mathrm{Sd} \\
\mathrm{CV}(\%)\end{array}$ & $\begin{array}{c}2.74 \\
0.39 \\
14.22\end{array}$ & $\begin{array}{c}2.81 \\
0.61 \\
\mathbf{2 1 . 7 6}\end{array}$ & $\begin{array}{c}2.44 \\
0.53 \\
\mathbf{2 1 . 6 1}\end{array}$ \\
\hline 10. & Length of Rachis (LR) (cm) & $\begin{array}{l}\mathrm{Sd} \\
\mathrm{CV}(\%)\end{array}$ & $\begin{array}{c}327.31 \\
71.39 \\
\mathbf{2 1 . 8 1}\end{array}$ & $\begin{array}{c}349.24 \\
68.51 \\
19.62\end{array}$ & $\begin{array}{c}300.31 \\
76.56 \\
\mathbf{2 5 . 4 9}\end{array}$ \\
\hline 11. & Length of leaf (LL) (cm) & $\begin{array}{l}\mathrm{X} \\
\mathrm{Sd} \\
\mathrm{CV}(\%)\end{array}$ & $\begin{array}{c}490.52 \\
102.80 \\
\mathbf{2 0 . 9 6}\end{array}$ & $\begin{array}{c}518.79 \\
86.62 \\
16.70\end{array}$ & $\begin{array}{c}432.82 \\
106.90 \\
\mathbf{2 4 . 7 0}\end{array}$ \\
\hline 12. & Heigth of Stem (HS) (cm) & $\begin{array}{l}X \\
\text { Sd } \\
\text { CV (\%) }\end{array}$ & $\begin{array}{c}110.66 \\
25.88 \\
\mathbf{2 3 . 3 9}\end{array}$ & $\begin{array}{l}104.92 \\
27.63 \\
\mathbf{2 6 . 3 4}\end{array}$ & $\begin{array}{l}82.99 \\
26.27 \\
\mathbf{3 1 . 1 7}\end{array}$ \\
\hline 13. & Girth of Stem (GC) (cm) & $\begin{array}{l}\mathrm{X} \\
\mathrm{Sd} \\
\mathrm{CV}(\%)\end{array}$ & $\begin{array}{l}96.37 \\
15.98 \\
16.58\end{array}$ & $\begin{array}{c}103.90 \\
25.31 \\
\mathbf{2 4 . 3 6}\end{array}$ & $\begin{array}{c}96.94 \\
9.11 \\
9.40\end{array}$ \\
\hline
\end{tabular}


Table 2. Honestly Significant Different (HSD) test of thirteen characters of three kopyor dwarf coconut from Pati

\begin{tabular}{lccc}
\hline \multirow{2}{*}{\multicolumn{1}{c}{ (Characters) }} & \multicolumn{3}{c}{ Accessions } \\
\cline { 2 - 4 } & KGD & KBD & KYD \\
\hline Number of bunches (NB) & $10.17 \mathrm{~b}$ & $9.91 \mathrm{~b}$ & $7.12 \mathrm{a}$ \\
Number Of fruits (NF) & $7.68 \mathrm{a}$ & $7.24 \mathrm{a}$ & $7.08 \mathrm{a}$ \\
Number of leaves (NL) & $13.17 \mathrm{ab}$ & $14.97 \mathrm{~b}$ & $11.55 \mathrm{a}$ \\
Number of leaflets (NLL) & $78.07 \mathrm{a}$ & $85.09 \mathrm{a}$ & $78.07 \mathrm{a}$ \\
Width of leaflet (WLL) & $3.99 \mathrm{a}$ & $4.09 \mathrm{a}$ & $3.84 \mathrm{a}$ \\
Length of leaflets (LLL) & $101.30 \mathrm{~b}$ & $105.51 \mathrm{~b}$ & $87.42 \mathrm{a}$ \\
Length of Petiole (LP) (cm) & $137.84 \mathrm{~b}$ & $146.03 \mathrm{~b}$ & $111.02 \mathrm{a}$ \\
Width of Petiole (WP (cm) & $5.04 \mathrm{a}$ & $6.33 \mathrm{a}$ & $5.01 \mathrm{a}$ \\
Thick of Petiole (TP) (cm) & $2.73 \mathrm{~b}$ & $2.76 \mathrm{~b}$ & $2.31 \mathrm{a}$ \\
Length of Rachis (LR) (cm) & $324.03 \mathrm{~b}$ & $339.53 \mathrm{~b}$ & $267.79 \mathrm{a}$ \\
Length of leaf (LL) (cm) & $491.23 \mathrm{~b}$ & $517.10 \mathrm{~b}$ & $406.86 \mathrm{a}$ \\
Height of Stem (HS) (cm) & $110.86 \mathrm{~b}$ & $94.44 \mathrm{ab}$ & $77.09 \mathrm{a}$ \\
Girth of Stem $(G S)(\mathrm{cm})$ & $96.16 \mathrm{a}$ & $106.03 \mathrm{a}$ & $96.38 \mathrm{a}$ \\
\hline
\end{tabular}

Numbers followed by the same letter on the same line is not significantly different

Table 3. Chlorophyll contens of three kopyor dwarf coconut from Pati

\begin{tabular}{lccc}
\hline \multicolumn{1}{c}{ Accessions } & Chlorophyll a & Chlorophyll b & Chlorophyll total \\
\hline Kopyor Green Dwarf & 0.0220 & 0.0176 & 0.0395 \\
Kopyor Brown Dwarf & 0.0220 & 0.0183 & 0.0402 \\
Kopyor Yellow Dwarf & 0.0116 & 0.0084 & 0.0196 \\
\hline
\end{tabular}

$\mathrm{CO} 2$ to produce carbohydrates and provide energy for the ecosystem as a whole. Carbohydrates produced in photosynthesis is converted into proteins, lipids, nucleic acids and other organic molecules. The study of Prihastanti (2010), showed that drought stress effect on chlorophyll content of cocoa seedling leaves. Water potential below 0 atm will inhibit the biosynthesis of chlorophyll and the formation protochlorofil (Salisbury and Ross, 1992 in Banyo et al, 2013).

\section{Path Analysis of Vegetatif and Reproductive Characters of three kopyor dwarf coconuts from Pati District}

Correlation between characters of Kopyor Green Dwarf, Kopyor Brown Dwarf, and Kopyor Yellow Dwarf is very important to know mainly correlation to production either direct or indirect relationship to the yield.
Correlation among Characters of Kopyor Green Dwarf

Simple correlation analysis (Table 4) showed no morphological characters of both vegetative and generative characters (numbers in bold) are correlated with NF. This illustrates that possibility for an early selection on the Kopyor Green Dwarf is very small if only based on simple correlation analysis, but that needs to be continued with path analysis (Table 5).

According to Dewey et al., (1959) in Selvarasu et al., (2013), a simple correlation analysis related to the results of the single variable will not provide a complete understanding of the importance of each character in determining the outcome. That requires the path analysis that is able to separate the correlation coefficients into the direct and indirect effects of each character so that the 
contribution of each character to yield can be calculated. Hussein and Hugo (2011) stated that unlike simple correlation is helps to measure the direct influence of one variable upon another through separation of the correlation coefficient into components of direct and indirect effects toward pinpointing the most influential predictor variable.

The results of the path analysis (Table 5) shows the characters of number of leaves, number of leaflets, height of stem, and girth of stem have a significantly direct effect to yield (number of fruits) with a correlation coefficient (r) respectively $0.563,0.592,0.486$, and 0.612 . These characters can be considered to be used in the selection process of Kopyor Green Dwarf for high yield assembly. For example, if the value of number of leaves character is raised one time of the value of standard deviation $(\mathrm{sd}=2.80)$ from the average value of number of leaves $(13,17)$, it is assumed that the increase in fruit production becomes 0.563 times that of the average production of the original number of fruit. The same explanation can be used for traits of number of leaflets, height of stem, and girth of stem.

The characters of leaves and stems are photosynthetic media and storage of food reserves of the plant. According to Mendez et al., (2011), during the period of vegetative growth and early production, carbon as assimilation result is temporarily stored in the stem and leaf midrib as carbohydrate reserves. The result of this is transported for seed and yield development. According to Rafii et al., (2013), the character of stems of plants from crosses of Dura with Pisifera correlated to the weight of fresh fruit bunches and palm oil output. Utilization of path analysis by Krualee (2013) also produced significant direct effect of characters of fresh mesokarp and number of fruits per bunch on the results of palm oil.

In case of no characters having a direct effect on the yield, indirectly effect through other characters can be used as selection criteria. In Table 5, character number of leaves not only has high positive direct effect on yield $(\mathrm{r}=$ $0.563)$, but also has indirect effect via characters length of petiole $(\mathrm{r}=0.422)$, and length of rachis $(\mathrm{r}=0.434)$. However, if there are characters are directly influencing yield, the indirect effect can be ignored.

Correlation among Characters of Kopyor Brown Dwarf

Results of simple correlation analysis (Table 6) of 13 characters of Kopyor Brown Dwarf showed no relationship between the twelve characters with the number of fruits. However, when it was further analyzed by path analysis (Table 7), characters of number of bunches $(r=0.424)$, length of petiole $(r=0.640)$, widht of petiole $(\mathrm{r}=0.871)$, length of rachis $(\mathrm{r}=$ $0.524)$, length of leaf $(r=0.626)$ showed direct significant effect on yield. This means selection for production improvements of Kopyor Brown Dwarf can be done through these characters.

In table 7, characters that have indirect effect are only length of petiole via number of leaves $(r=0.444)$, number of leaflets $(r=0.456)$, width of petiole $(\mathrm{r}=0.534)$; width of petiole via length of petiole $(r=0.728)$, thick of petiole $(r=$ $0.681)$, length of rachis $(r=0.644)$, length of leaf $(r=-0.571)$; length of rachis via length of leaf $(r$ $=0.416)$; length of leaf via length of rachis $(r=$ $0.497)$. These characters are useful if there is no direct effect on yield.

\section{Correlation among Characters of Kopyor Yellow Dwarf}

Appearance of Kopyor Yellow Dwarf based on simple correlation analysis (Table 8) doesn't show relationship between twelve vegetative and generative characters with the number of fruits (NF) as observed in Kopyor Brown Dwarf. The results of path analysis (Table 9) shows the opposite. There are five characters that directly affect significantly to NF. That characters are width of leaflets ( $\mathrm{r}$ $=0.8413)$, length of leaflets $(r=0.5617)$, thick of petiole $(\mathrm{r}=0.5864)$, length of rachis $(\mathrm{r}=$ $0.580)$, and length of leaf $(\mathrm{r}=0.923)$. Thus, selection for the Kopyor Yellow Dwarf for yield improvement can be done directly through the characters of width of leaflets, length of leaflets, thick of petiole, length of rachis, and length of leaf, the whole characters are as the media of photosynthesis. Indirect effect on yield 
Cord 2017, 33 (1)

Table 4. Correlation coefficient of thirteen characters of Kopyor Green Dwarf

\begin{tabular}{|c|c|c|c|c|c|c|c|c|c|c|c|c|c|}
\hline Characters & NB & $\mathrm{NF}$ & NL & NLL & WLL & LLL & LP & WP & $\mathrm{TP}$ & LR & LL & HS & GS \\
\hline NB & 1 & & & & & & & & & & & & \\
\hline NF & -0.088 & 1 & & & & & & & & & & & \\
\hline NL & -0.074 & 0.238 & 1 & & & & & & & & & & \\
\hline NLL & -0.160 & 0.261 & $0.556^{*}$ & 1 & & & & & & & & & \\
\hline WLL & 0.138 & 0.005 & 0.070 & 0.009 & 1 & & & & & & & & \\
\hline LLL & -0.024 & 0.130 & 0.290 & $0.431^{*}$ & -0.349 & 1 & & & & & & & \\
\hline LP & 0.149 & 0.087 & 0.750 & 0.701 & -0.084 & 0.242 & 1 & & & & & & \\
\hline WP & -0.191 & 0.197 & 0.287 & $0.455^{*}$ & 0.045 & -0.080 & 0.312 & 1 & & & & & \\
\hline $\mathrm{TP}$ & -0.049 & 0.014 & 0.613 & $0.678^{* *}$ & 0.162 & 0.067 & $0.612^{* *}$ & 0.167 & 1 & & & & \\
\hline LR & -0.003 & 0.007 & 0.772 & $0.748^{* *}$ & 0.038 & 0.179 & $0.836^{* *}$ & 0.260 & $0.716^{* *}$ & 1 & & & \\
\hline LL & -0.105 & 0.197 & 0.712 & $0.709^{* *}$ & 0.040 & 0.100 & $0.755^{* *}$ & $0.422 *$ & $0.638^{* *}$ & $0.846^{* *}$ & 1 & & \\
\hline HS & $0.494^{*}$ & $\mathbf{0 . 3 3 3}$ & -0.033 & -0.064 & -0.140 & 0.117 & 0.124 & $0.504 *$ & 0.173 & 0.149 & 0.042 & 1 & \\
\hline GS & 0.094 & 0.367 & 0.503 & $0.540^{*}$ & -0.128 & $0.556^{*}$ & $0.410^{*}$ & -0.129 & $0.452 *$ & $0.492 *$ & $0.511^{*}$ & 0.397 & 1 \\
\hline
\end{tabular}


Table 5. Phenotypic matrix of path coefficient of direct and indirect effects of vegetative and generative characters on number of fruit of Kopyor Green Dwarf

\begin{tabular}{lccccccccccccc}
\hline Characters & NB & NL & NLL & WLL & LLL & LP & WP & TP & LR & LL & HS & GS \\
\hline NB & $\underline{0.384}$ & -0.042 & -0.095 & 0.011 & -0.008 & -0.024 & 0.028 & 0.012 & -0.001 & -0.042 & 0.243 & 0.058 \\
NL & -0.028 & $\underline{0.563^{* *}}$ & 0.329 & 0.005 & 0.095 & -0.095 & -0.042 & -0.150 & 0.308 & 0.283 & -0.016 & 0.308 \\
& & & & & & & & & & & & \\
NLL & -0.062 & 0.313 & $\underline{0.592^{* *}}$ & 0.001 & 0.141 & -0.089 & -0.067 & -0.165 & 0.298 & 0.282 & -0.031 & 0.331 \\
& & & & & & & & & & & & \\
WLL & 0.053 & 0.039 & 0.005 & $\underline{0.078}$ & -0.114 & 0.011 & -0.007 & -0.040 & 0.015 & 0.016 & -0.068 & -0.078 \\
LLL & 0.009 & 0.163 & 0.255 & -0.027 & $\underline{0.328}$ & -0.031 & 0.012 & -0.016 & 0.071 & 0.040 & 0.057 & 0.340 \\
LP & 0.057 & $0.422^{*}$ & 0.414 & -0.007 & 0.079 & $\underline{-0.123}$ & 0.012 & -0.149 & 0.334 & 0.300 & 0.060 & 0.255 \\
WP & -0.073 & 0.162 & 0.269 & 0.004 & -0.026 & -0.040 & -0.148 & -0.041 & 0.104 & 0.168 & -0.245 & -0.080 \\
TP & -0.019 & 0.345 & 0.401 & 0.013 & 0.022 & -0.078 & -0.024 & $\underline{-0.244}$ & 0.286 & 0.254 & 0.084 & 0.277 \\
LR & -0.001 & $0.434 *$ & $0.442 *$ & 0.003 & 0.059 & -0.106 & 0.038 & -0.175 & $\underline{0.399}$ & 0.337 & 0.072 & 0.301 \\
LL & -0.040 & 0.401 & $0.419 *$ & 0.003 & 0.033 & -0.096 & -0.062 & -0.156 & 0.338 & $\underline{0.398}$ & 0.020 & 0.313 \\
HS & 0.192 & -0.019 & -0.038 & -0.011 & 0.038 & -0.016 & 0.074 & -0.042 & 0.060 & 0.017 & $\underline{0.486}$ & 0.243 \\
GS & 0.036 & 0.283 & 0.319 & -0.010 & 0.182 & -0.053 & 0.019 & -0.110 & 0.196 & 0.203 & 0.193 & $\underline{0.612} * *$ \\
\hline
\end{tabular}

T $0.01=2.831 \quad \mathrm{t} 0.05=2.08$ 
Cord 2017, 33 (1)

Table 6. Coefficient correlation of thirteen characters of Kopyor Brown Dwarf

\begin{tabular}{|c|c|c|c|c|c|c|c|c|c|c|c|c|c|}
\hline Characters & NB) & NF & NL & NLL & WLL & LLL & LP & WP & TP & LR & $\mathrm{LL}$ & $\mathrm{HS}$ & GS \\
\hline NB & 1 & & & & & & & & & & & & \\
\hline NF & -0.254 & 1 & & & & & & & & & & & \\
\hline NL & 0.189 & -0.054 & 1 & & & & & & & & & & \\
\hline NLL & -0.065 & 0.130 & 0.539 & 1 & & & & & & & & & \\
\hline WLL & -0.057 & -0.352 & 0.377 & 0.193 & 1 & & & & & & & & \\
\hline LLL & -0.192 & 0.196 & 0.351 & 0.049 & -0.030 & 1 & & & & & & & \\
\hline LP & -0.004 & 0.154 & 0.695 & 0.714 & 0.305 & 0.187 & 1 & & & & & & \\
\hline WP & -0.110 & 0.013 & 0.711 & 0.787 & 0.348 & 0.245 & 0.836 & 1 & & & & & \\
\hline $\mathrm{TP}$ & -0.171 & 0.029 & 0.561 & 0.614 & 0.174 & 0.160 & 0.563 & 0.782 & 1 & & & & \\
\hline LR & -0.065 & -0.061 & 0.513 & 0.464 & 0.338 & 0.403 & 0.640 & 0.740 & 0.572 & 1 & & & \\
\hline LL & 0.072 & 0.138 & 0.523 & 0.387 & 0.315 & 0.415 & 0.611 & 0.656 & 0.460 & 0.794 & 1 & & \\
\hline HS & 0.354 & -0.087 & 0.312 & -0.136 & 0.001 & 0.253 & 0.031 & 0.143 & 0.169 & 0.257 & 0.425 & 1 & \\
\hline GS & -0.281 & 0.013 & -0.271 & -0.145 & -0.104 & -0.466 & -0.143 & -0.262 & 0.099 & 0.307 & 0.356 & 0.296 & 1 \\
\hline
\end{tabular}

Table 7. Phenotypic matrix of path coefficient of direct and indirect effect of vegetative and generative characters on number of fruit of Kopyor Brown Dwarf

\begin{tabular}{|c|c|c|c|c|c|c|c|c|c|c|c|c|}
\hline Characters & NB & NL & NLL & WLL & LLL & LP & WP & $\mathrm{TP}$ & LR & LL & HS & GS \\
\hline NB & $\underline{0.424^{*}}$ & -0.014 & -0.015 & -0.022 & -0.003 & -0.003 & 0.098 & -0.047 & -0.034 & 0.045 & -0.010 & -0.066 \\
\hline NL & 0.080 & $-\underline{0.073}$ & 0.127 & 0.143 & 0.006 & $0.444 *$ & -0.319 & 0.1548 & 0.268 & 0.327 & 0.009 & -0.063 \\
\hline NLL & -0.028 & -0.039 & $\underline{0.236}$ & 0.073 & 0.001 & $0.456^{*}$ & -0.285 & 0.167 & 0.243 & 0.242 & 0.004 & -0.034 \\
\hline WLL & -0.024 & -0.027 & $\overline{0.046}$ & $\underline{0.378}$ & 0.001 & 0.195 & -0.303 & 0.048 & 0.177 & 0.197 & -0.00003 & -0.024 \\
\hline LLL & -0.081 & -0.025 & 0.012 & -0.011 & $\underline{0.016}$ & 0.120 & -0.213 & 0.044 & 0.211 & 0.260 & -0.007 & -0.104 \\
\hline LP & -0.002 & -0.050 & 0.169 & 0.115 & 0.003 & $\underline{0.640 * *}$ & $0.728 * *$ & 0.155 & 0.335 & 0.382 & -0.001 & -0.033 \\
\hline WP & -0.047 & -0.052 & 0.186 & 0.132 & 0.004 & 0.534 & $0.871 * *$ & 0.216 & 0.387 & 0.411 & -0.004 & -0.061 \\
\hline $\mathrm{TP}$ & -0.073 & -0.041 & 0.145 & 0.066 & 0.003 & 0.360 & $0.681 * *$ & $\underline{0.276}$ & 0.299 & 0.288 & -0.005 & 0.023 \\
\hline LR & -0.028 & -0.037 & 0.110 & 0.128 & 0.007 & 0.410 & $0.644 * *$ & 0.158 & $\underline{0.524^{*}}$ & $0.497 *$ & -0.007 & -0.072 \\
\hline LL & 0.031 & -0.038 & 0.091 & 0.119 & 0.007 & 0.390 & $-0.571 * *$ & 0.181 & $0.416^{*}$ & $\underline{0.626}^{* *}$ & -0.012 & -0.083 \\
\hline HS & 0.150 & -0.023 & -0.032 & 0.0004 & 0.004 & 0.020 & -0.125 & 0.047 & 0.135 & 0.266 & -0.028 & -0.069 \\
\hline GS & -0.119 & 0.020 & -0.034 & -0.039 & -0.008 & -0.091 & 0.228 & 0.027 & -0.194 & -0.223 & $\overline{0.008}$ & 0.234 \\
\hline
\end{tabular}


Cord 2017, 33 (1)

Table 8. Coefficient correlation of thirteen characters of Kopyor Yellow Dwarf

\begin{tabular}{|c|c|c|c|c|c|c|c|c|c|c|c|c|c|}
\hline Characters & $N B$ & $N F$ & $N L$ & $N L L$ & WLL & $L L L$ & $L P$ & $W P$ & $T P$ & $L R$ & $L L$ & $H S$ & $G S$ \\
\hline$N B$ & 1 & & & & & & & & & & & & \\
\hline$N F$ & 0.373 & 1 & & & & & & & & & & & \\
\hline$N L$ & 0.453 & 0.241 & 1 & & & & & & & & & & \\
\hline$N L L$ & -0.377 & 0.023 & -0.065 & 1 & & & & & & & & & \\
\hline WLL & 0.281 & -0.128 & 0.631 & -0.334 & 1 & & & & & & & & \\
\hline$L L L$ & -0.318 & 0.157 & -0.150 & 0.571 & -0.249 & 1 & & & & & & & \\
\hline$L P$ & 0.297 & 0.220 & 0.732 & -0.074 & 0.656 & -0.161 & 1 & & & & & & \\
\hline$W P$ & 0.312 & 0.064 & 0.594 & -0.215 & 0.664 & -0.388 & 0.591 & 1 & & & & & \\
\hline$T P$ & 0.338 & 0.243 & 0.616 & -0.401 & 0.727 & -0.203 & 0.690 & 0.698 & 1 & & & & \\
\hline$L R$ & 0.324 & 0.184 & 0.691 & -0.323 & 0.663 & -0.155 & 0.730 & 0.777 & 0.910 & 1 & & & \\
\hline$L L$ & 0.400 & 0.267 & 0.685 & -0.304 & 0.662 & -0.246 & 0.803 & 0.748 & 0.935 & 0.954 & 1 & & \\
\hline$H S$ & -0.413 & 0.198 & 0.180 & 0.384 & -0.086 & 0.372 & 0.184 & -0.033 & 0.098 & 0.082 & 0.098 & 1 & \\
\hline$G S$ & 0.014 & 0.108 & 0.491 & -0.185 & 0.409 & -0.126 & 0.359 & 0.505 & 0.439 & 0.476 & 0.371 & 0.055 & 1 \\
\hline
\end{tabular}


Cord 2017, 33 (1)

Table 9. Phenotypic matrix of path coefficient of direct and indirect effect of vegetative and generative characters on number of fruit of Kopyor Yellow Dwarf

\begin{tabular}{|c|c|c|c|c|c|c|c|c|c|c|c|c|}
\hline Characters & NB & NL & NLL & WLL & LLL & LP & WP & $\mathrm{TP}$ & LR & LL & HS & GS \\
\hline NB & $\underline{0.301}$ & 0.126 & -0.112 & -0.236 & -0.164 & 0.053 & 0.116 & 0.198 & -0.312 & 0.409 & -0.020 & 0.003 \\
\hline NL & 0.136 & $\underline{0.278}$ & 0.020 & $-0.531^{*}$ & -0.084 & 0.131 & 0.220 & 0.361 & $0.901 * *$ & $0.701 * *$ & 0.001 & 0.092 \\
\hline NLL & 0.113 & -0.018 & $\underline{-0.302}$ & 0.281 & 0.321 & -0.039 & -0.078 & -0.235 & $0.510 *$ & -0.311 & 0.018 & -0.035 \\
\hline WLL & 0.085 & 0.175 & 0.101 & $\underline{0.841 * *}$ & -0.140 & 0.118 & 0.246 & $0.426^{*}$ & -0.347 & $0.677 * *$ & -0.004 & 0.077 \\
\hline LLL & -0.096 & -0.042 & -0.173 & 0.210 & $\underline{0.562} * *$ & -0.029 & -0.144 & -0.119 & 0.248 & -0.252 & 0.018 & -0.024 \\
\hline LP & 0.089 & 0.203 & 0.022 & $-0.552 *$ & -0.090 & $\underline{0.180}$ & 0.219 & 0.405 & 0.166 & $0.821 * *$ & 0.009 & 0.067 \\
\hline WP & 0.094 & 0.165 & 0.065 & $-0.559^{*}$ & -0.218 & 0.106 & $\underline{0.371}$ & 0.409 & 0.241 & $0.765 * *$ & -0.002 & -0.095 \\
\hline $\mathrm{TP}$ & 0.102 & 0.171 & 0.121 & -0.312 & -0.114 & 0.124 & 0.259 & $\underline{0.586}^{* *}$ & -0.354 & $0.956 * *$ & 0.005 & 0.082 \\
\hline LR & 0.098 & 0.192 & 0.098 & -0.558 & -0.087 & 0.131 & 0.288 & $0.534 *$ & $\underline{0.580}^{* *}$ & $0.976^{* *}$ & 0.004 & 0.089 \\
\hline LL & 0.120 & 0.190 & 0.092 & $0.557^{*}$ & 0.138 & 0.144 & 0.277 & $0.548 *$ & $0.507 * *$ & $\underline{0.923}^{* *}$ & 0.005 & 0.069 \\
\hline HS & -0.124 & 0.050 & -0.116 & 0.072 & 0.209 & 0.033 & -0.012 & 0.056 & -0.131 & 0.100 & $\underline{0.048}$ & 0.069 \\
\hline GS & 0.004 & 0.136 & 0.056 & -0.344 & -0.071 & 0.064 & 0.187 & 0.254 & -0.352 & 0.380 & 0.003 & $\underline{0.187}$ \\
\hline
\end{tabular}


character only showed by characters width of leaflets via number of leaflets $(-0.531)$, length of petiole $(\mathrm{r}=-0.552)$, Width of petiole $(\mathrm{r}=$ $0.559)$, length of rachis $(\mathrm{r}=-0.558)$, length of leaf $(\mathrm{r}=0.557)$; thick of petiole via width of leaflets $(r=0.426)$, length of rachis $(r=0.534)$, length of leaf $(\mathrm{r}=0.548)$; length of rachis via number of leaves $(r=0.901)$, number of leaflets $(r=0.510)$, length of leaf $(r=0.507)$; and length of leaf via number of leaves $(r=0.701)$, width of laeflets $(r=0.677)$, length of petiole $(r=0.821)$, width of petiole $(r=0.765)$, thick of petiole $(r=$ $0.956)$, length of rachis $(r=0.976)$. In case there are direct effects on yield, these characters could be ignored.

In general, coefficient correlation of thirteen characters of Kopyor Green Dwarf, Kopyor Brown Dwarf, and Kopyor Yellow Dwarf did not show relationship between the characters yield components and nut yields. Different results reported by Namboothiri et al., (2007) that characters of length of petiole correlated to nut yield; characters number of leaves, length of leaf, and length of petiole have positive correlation to nut yield (Natarajan et al., 2010). Different with coefficient correlation result, path coefficient analysis showed that component characters have direct effects on nut yield, namely, number of leaves, number of leaflets, height of stem, and girth of stem for Kopyor Green Dwarf; number of bunch, length of petiole, width of petiole, length of rachis, length of leaflets for Kopyor Brown Dwarf ; and width of leaflets, length of leaflets, thick of petiole, length of rachis and length of leaf for Kopyor Yellow Dwarf. Sindhumole and Ibrahim (2000) reported the similar results that vegetative characters had higher direct effect on nut yield than reproductive characters. The effect of trunk height was the most prominent but was highly modified due to the indirect effects through girth of stem and female flowers.

\section{Conclusion}

Appearance of Kopyor Brown Dwarf is more vigorous than other two types of kopyor dwarf coconut, while the lowest performance of vigour showed by Kopyor Yellow Dwarf is supported by data chlorophyll content. Selection to improve yield production of Kopyor Green Dwarf can be done through the characters of number of leaves, number of leaflets, height of stem, and girth of stem. For Kopyor Brown Dwarf selection can be done through number of bunches, length of petiole, width of petiole, length of rachis, and length of leaf. While in Kopyor Yellow Dwarf selection can be done through characters width of leaf, length of leaf, thick of petiole, length of rachis and length of leaf.

\section{References}

Ahamed K.U., Akter B., Ara N., Hossain M.F., and Moniruzzaman M. 2015. Heritabiliy, correlation, and path coefficient analysis in fifty seven okra genotypes. Int J Appl Sci Biotechnol, Vol 3(1): 127-133.

Ali Y., Farhatullah., Rahman H., Nasim A., Azam S.M., and Khan A. 2013. Heritability and correlation analysis for morphological and biochemical traits in Brassica carinata. Sarhad J. Agric. Vol.29 (3): $359-370$

Banyo Y.E., Nio Song Ai, Siahaan P., Tangapo A.M. 2013. Konsentrasi klorofil daun padi pada saat kekurangan air yang diinduksi dengan polietilen glikol. Jurnal Ilmiah Sains Vol 13 No. 1.

Dwitasari L. 2014. Ko-sensitisasi xantofil pada sistim sel surya tersensitisasi klorofilin. Skripsi Pasca Sarjana, Universitas Gajah Mada, Tahun 2014.

Ejaz-Ul-Hasan., Mustafa H.S.B., Tahira B., Mahmood T. 2014. Genetic variability, correlation and path analysis in advanced lines of rapeseed (Brasicca napus L.) for yield components. Cercetări Agronomice în Moldova Vol. XLVII, No. 1 (157): 7179.

Gelalcha S., and Hanchinal R.R. 2013. Correlation and path analysis in yield and yield components in spring bread wheat (Triticum aestivum L.) genotypes under irrigated condition in Southern India. African Journal of Agricultural Research. Vol 8(24). Pp.3186-3192. June 2013. 
Hartati S., A. Setiawan, B. Heliyanto, and Sudarsono. 2012. Keragaman genetik, heritabilitas, dan korelasi antara karakter 10 genotipe terpilih jarak pagar (Jatropha curcas L.). Jurnal Littri 18 (2): 74-80

Huang B., Yang Y., Luo T., Shu Wu., Xuezhu Du., Cai D., Eibertus N. van Loo., Bangquan Huang. 2013. American Journal of Plant Sciences, 2013, 4, 42-47

Hussein S., and Hugo A. 2011. Determination of selection criteria for seed yield and seed oil content in Vernonia (Vernonia galamensis variety ethiopica). Industrial Crops and Products 33 (2011) 436-439. Journal hompage: www. Elsevier.com/ locate/indcrop. Diunggah tanggal 11 Maret 2015.

Iqbal M., Ijaz U., Smiullah., Iqbal M., Mahmood K., Najeebullah M., Abdullah, Niaz S., Sadaqat H.A. 2013. Genetic divergence and path coefficient analysis for yield related attributes in sunflower (Helianthus annuus L.) under less water conditions at productive phase. Plant Knowledge Journal Vol. 2(1): 20- 23

Kassahun B.M., Alemaw G., and Tesfaye B. 2013. Correlation studies and path coefficient analysis for seed yield and yield components in Ethiopian coriander accessions. African Crop Journal. Vol. 21, No.1, pp 51-59. Frican Crop Science Society.

Krualee S., Sdoodee S., Eksomtramage T., and Sereeprasert V. 2013. Correlation and path analysis of palm oil yield components in oil palm (Elaeis guineensis Jacq). Kasetsart J. (Nat. Sci.) 47: 528 - 533 (2013)

Maskromo I., Novarianto, H. Sukendah, Sukma D. Sudarsono. 2013. Productivity of Three Dwarf Kopyor Coconut Varieties from Pati, Central Java, Indonesia. International Journal on Coconut R\&D. Vol 29 No. 2: 19-28.

Maskromo I., E.T. Tenda, Tulalo M.A. Novarianto H., Sukma D., Sukendah,
Sudarsono. 2015. Keragaman fenotipe dan genetik tiga varietas kelapa genjah kopyor asal pati Jawa Tengah. Jurnal Penelitian Tanaman Industri Vol 21 No 1. Hal 1-8.

Mendez A.M, D. Castilo, A. Del Pozo, Matus I., and Morcuende R. 2011. Differences in stem soluble carbohydrates contents among recombinant chromosome substitution lines (RCSLs) of Barley under drought in a Mediterranean-type environment. Agronomy Research 9 (II): 433-438.

Namboothiri C.G.N., Nilar N., and Parthasarathy V.A. 2007. Correlation and path coefficient analysis in the F2 population in coconut. Indian Journal of Horticulture. Vol.64. Issue: 4. Pp.450-453.

Natarajan C., K. Ganesamurthy, M. Kavitha. 2010. Genetic variability in coconut (Cocos nucifera). Electronic Journal of Plant Breeding I (5): 1367-1370.

Nio Song Ai, dan Banyo Y. 2011. Konsentrasi klorofil daun sebagai indicator kekurangan air pada tanaman. Jurnal Ilmiah Sains. Vol. 11, No. 2. Hal. 166-173. email: nio_ai@yahoo.com

Rafii M.Y., Z.A. Isa, A. Kushairi, G.B. Saleh, M.A. Latif. 2013. Variation in yield components and vegetatif traits in Malaysian oil palm (Elaeis guineensis Jacq.) dura $\mathrm{x}$ pisifera hybrids under variations planting densities. Industrial Crops and Products 46(2013): 147-157. Journal homepage: www.elsevier.com/ locate/indcrop. Diunggah tanggal 1 April 2015 .

Reddy B.R., Reddy M., Reddy D.S., Begum H. 2013. Correlation and path analysis studies for yield and quality traits in tomato (Solanum lycopersicum L.). IOSR Journal of Agriculture and Veterinary Science (IOSR-JAVS) e-ISSN: 23192380, p-ISSN: 2319-2372. Volume 4, Issue 4 (Jul. - Aug. 2013), PP 56-59 www.iosrjournals.org www.iosrjournals.org 56. 
Rohaeni W.R. and Permadi K. 2012. Analisis sidik lintas beberapa karakter komponen hasil terhadap daya hasil padi sawah pada aplikasi agrisimba. AGROTROP 2(2): 185-190.

Selvarasu A., and Kandhasamy R. 2013. Analysis of variability, correlation and path coefficient in induce mutants of Glory Lily (Gloriosa superba L.). International Journal of Plant Breeding 7 (1), 69.75

Singh R.K. and Chaudary B.D. 1977. Biometrical Methods in Quantitative Genetic Analysis. Kalyani Publishers. New Delhi. Ldhiana. P.200.

Sindhumole P., and Ibrahim K.K. 2000. Path analysis of nut yield in cultivars of coconut (Cocos nucifera L.). South Indian Horticulture Journal, Vol.48. No.1/6. Pp.160-162.

Sirait J. 2008. Luas daun, kandungan klorofil dan laju pertumbuhan rumput pada naungan dan pemupukan yang berbeda. JITV, Vol. 13, No.2. Hal. 109-116.

Tenda, E.T. dan Miftahorrachman. 2014. Hubungan antara karakter vegetatif dengan produksi pati sagu baruq (Arenga macrocarpha Becc.) asal Kabupaten Sangihe. Jurnal Littri 20 (4) 203-210.

Yucel D.O., Anlarsal A.E., Yucel C. 2006. Genetik variability, correlation and path analysis of yiled, and yield components in chickpea (Cicer arietinum L.). Turk J. Agric. For 30 (2006) 183-188. 